\title{
Dispute over insect resistance to crops
}

[WASHINGTON] Academic scientists and industry are in dispute about efforts to prevent the emergence of insect resistance to new, genetically engineered crops, a development that would render useless a naturally occurring insecticide relied on by organic farmers.

At issue are corn and cotton engineered to produce a toxin made by the soil bacterium Bacillus thuringiensis $(B t)$. The toxin defends plants against common pests including cotton bollworm and tobacco budworm, which both afflict cotton, and the European corn borer. Bt cotton has been developed by Monsanto; the major manufacturer of Bt corn is Novartis Seeds. Crops were first planted commercially in 1996.

About 2.1 million acres, or 15 per cent of the US cotton crop, have been planted with $B t$ cotton this season. Bt corn has been planted on about 7.25 million acres, or 9 per cent of corn acreage.

Critics, led by the Union of Concerned Scientists (UCS), argue that large-scale planting will put such intense genetic pressure on insects that resistance to $B t$ toxin will emerge rapidly. They claim resistance management plans (RMPs) are inadequate.

The Environmental Protection Agency (EPA) worked out provisional RMPs with companies as part of conditional approvals for planting Btcrops. Further development of these is required if approval is to be extended beyond 2001.

Current resistance management strategies for $B t$ allow resistant insects that survive in $B t$

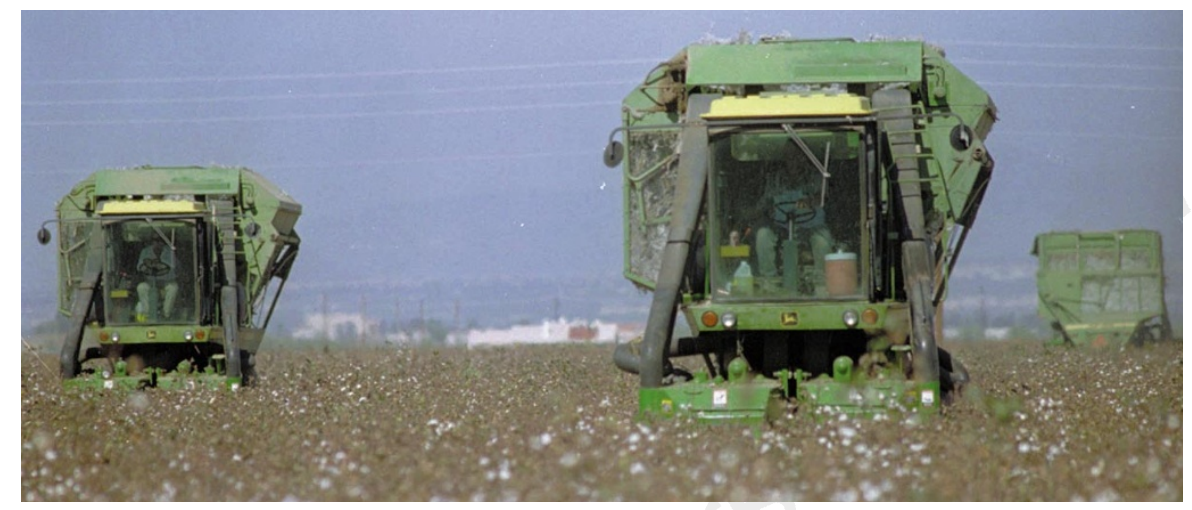

Cotton harvest: infestations of the genetically engineered crop aroused fears about resistance.

fields to mate with non-resistant insects from adjacent "refuges" where non- $B t$ plants are grown. The aim is to drown resistance genes in a larger gene pool.

But the size of refuge necessary to ensure resistance genes are drowned out is disputed. Under Monsanto's plan, farmers must plant at least four per cent of their cotton crop with non-Bt plants. Bruce Tabashnik, head of the entomology department at the University of Arizona, one of UCS's scientific advisers, says that 20-40 per cent would be safer.

Fears were prompted by infestations of Monsanto's Bt cotton in Texas last year by cotton bollworms (Nature 382, 289; 1996). The company and the EPA say that unusually large populations of bollworm were responsible, but critics claim that levels of Bt generated by the cotton plants were not high enough. They say that if the cotton is to continue in use,

\section{Swiss research resting on its laurels}

[MUNICH] Swiss science is still of high quality, but it is living off its past successes, says a report from the Swiss Science Council that analyses the state of research and universities.

The report warns that recent years of falling investment in research mean current high standards "cannot be guaranteed in the future".

Science council reports are prepared every four years and are used by the federal government to help develop its short-term science and higher education policies. The current report has been prepared for the 2000-2003 financial planning period.

Since 1992, Swiss spending on research has stagnated at around SFr9 billion ( $\$ 6$ billion), and the proportion of this provided by industry has fallen from 75 per cent to less than 70 per cent. The report does not criticize the relative reduction in industrial research and development investment, since the proportion of spending on research by industry in Switzerland has always been much higher than in other European countries. But it says that the state should make up for the reduction in future.

The report says new money should be used to support Switzerland's strengths such as biomedical and clinical research, computational physics and material sciences.

A second report on universities says that support for the so-called Mittelbau in Switzerland - the 20,000 or so doctoral students, research fellows, assistant and associate professors - is a "central problem of the science system". The Mittelbau are usually on short-term contracts and have little responsibility within their institutes, whose hierarchical systems deny them freedom in their research and freedom to teach.

The report says working conditions and career prospects of the Mittelbau should be improved by the universities and the federal and canton governments. Training and support programmes should be available and grants should be provided to encourage the notoriously non-mobile Swiss $\mathrm{PhD}$ students to study abroad. Quirin Schiermeier refuges should be increased to ensure they hold enough non-resistant insects.

Monsanto spokesman Gary Barton says that the plan was developed using the "best available science" and points out there is an option for a 20 per cent refuge which growers may spray with non- $B t$ insectcides to protect crops without fostering Btresistance.

Critics say too little is known about the issues - from insect movement and mating patterns to naturally occurring rates of insect resistance - to make current RMPs work effectively, and that companies are not doing the research that would improve them.

To bolster its case, the UCS will summon six scientists to Washington next month to draft alternatives to existing RMPs. Environmentalists are also agitating for the EPA to seek outside advice on the soundness of its resistance management science, a move theEPA is considering.

Tabashnik says that current EPA-approved plans are "based on economic acceptability to the companies selling the products".

But Janet Andersen, director of EPA's biopesticides and pollution prevention division, says it is "premature" to judge the effectiveness of the plans because crops are in only their second commercial season.

Jeffrey Stein, regulatory manager at Novartis, calls it "ludicrous" to suggest that companies would neglect RMPs in the quest for short-term profits. He says Novartis will spend more than $\$ 250,000$ on resistance research this year because, while resistance of insects in the wild to Bt corn is "strictly hypothetical" at the moment, "it may happen".

Monsanto's Barton agrees and says that the benefits of the new crops far outweigh the risks, increasing yields while eliminating the use of one million litres of chemical insecticides. "Do the critics just want to keep spraying?" he says.

Refuges for corn crops are not required under current RMPs, a further cause for criticism. Industry argues that, with 91 per cent of US corn acreage not planted with $B t$ corn, ample natural refuge already exists for present needs. MeredithWadman 